Perguruan Tinggi Berbasis Pesantren dan Peranannya dalam Deradikalisasi Agama

\title{
PEGURUAN TINGGI BERBASIS PESANTREN DAN PERANANNYA DALAM DERADIKALISASI AGAMA
}

\author{
Fadlilah \\ Tarbiyah, IAI Al - Falah As - sunniyyah Kencong \\ fadlillahz111@gmail.com
}

\begin{abstract}
Nation Indonesia As a big country and has a lot of diversity, it certainly becomes a challenge for how to make a country that is geographically very large and has several religions, ethnicities and cultures. Islam is the most widely adhered to by its inhabitants by carrying out the ideals of rahmatan lil 'alamin. But the teachings of rahmatan lil 'alaminare often reduced by dogmatic groups who hold radical views to justify acts of violence in the name of religion. Deradicalisation steps are needed to build more humanist Islamic education. Higher education as one of the pillars of education in Indonesia has an important role in deradicalization, especially Islamic boarding schools.
\end{abstract}

Keywords: Islamic Boarding Schools, Deradicalization of Religion

\begin{abstract}
ABSTRAK
Bangsa Indonesia Sebagai Negara yang besar dan mempunyai keanekaragaman yang banyak tentunya menjadi tantangan tersendiri bagaimana menjadikan Negara yang secara geografis sangat besar dan mempunyai beberaga agama, etnis dan budayanya. Islam merupakan agama yang paling banyak dianut oleh penduduknya dengan mengusung cita-cita rahmatan lil 'alamin.Namun ajaran rahmatan lil 'alamintersebut sering direduksi oleh kelompok dogmatik yang berpaham radikal untukmenjustifikasi aksi-aksi kekerasan atas nama agama. Langkah-langkah deradikalisasidiperlukan untuk membangun pendidikan Islam yang lebih humanis.Perguruan tinggi sebagai salah satu pilar pendidikan di Indonesia mempunyai peranan penting dalam deradikalisasi khususnya perguruan tinggi yang berbasis pesantren.
\end{abstract}

Kata Kunci : Pesantren, Deradikalisasi Agama

\section{PENDAHULUAN}

Indonesia dengan beberapa ragam budaya, suku, ras dan Agama dikenal sebagai bangsa yang damai dan penuh toleransi.Namun, beberapa kejadian akhir ini melunturkan identitas Indonesia yang dikenal dengan pluralismenya.Kekerasan mengatasnamakan agama menjadi trending topic dan menjadi sorotan dunia. Hal

FaLASIFA, Vol. 10 Nomor 1 Maret 2019 | 65 


\section{Fadlilah}

tersebut jelas menggambarkan bahwa toleransi agama dan kerukunan sosial selama ini dibangun di atas fondasi pasir, bukan batu yang kuat.Sekali lagi, kita merasa sedih sekaligus kecewa, karena maraknya tindakan kekerasan yang justru mengatasnamakan pembelaan agama dan menegakkan agama.Padahal, agama apapun selalu membawa pesan cinta kasih dan damai. Masalah kekerasan semakin menjadi semakin rumit dan kompleks ketika dipraktikan dengan legitimasi agama dan etnis.Menurut johan gatung, kekerasan merupakan satu sifat atau keadaan yang mengandung kekuatan, tekanan, dan paksaan. ${ }^{1}$

Kekerasan dalam agama muncul dalam tiga pola atau bentuk.Pertama, kekerasan internal, yakni ketika seseorang atau sekelompok orang melakukan autokritikterhadap hal-hal yang stagnan dalam agama atau munculnya gerakan dinamis yang menghendaki sebuah pembaruan agama. Kedua, kekerasan juga muncul ketika di tengah masyarakat muncul ketidakadilan atau penguasa yang zhalim, lalu agama akan tampil sebagai pembebas. Ketiga, kekerasan berlabel agama juga akan dengan mudah muncul ketika satu agama merasa terancam oleh pengaruh agamaagama lain. ${ }^{2}$

Beberapa fenomena kekerassan yang mengatasnamakan agama atau yang biasa disebut radikalisme agama sudah mulai mengakar. Aksi teror yang tiada henti, pengeboman di sejumlah titik ditanah air yang mengatasnamakan jibad fi sabilillah sebagaimana yang didalangi oleh JI (jamaah islamiyah) pada malam natal tahun 2000 di bali, dan 2002 di hotel maririot jakarta. Begitu juga tahun-tahun berikutnya bom bali II 2005, bom tentena 2005, bom solo 2011, dan 2012, bom sarinah 2016 silam dan yang terbaru di markas kepolisian sektor bontoala makasar 2018.

Menurut mantan Direktur Jenderal Pendidikan Islam Nur Syam, menyatakan bahwa jalan yang terbaik ke depan untuk mengusung deradikalisasi adalah dengan membangun deradikalisasi agama melalui lembaga pendidikan. Dan untuk itu sangat diperlukan gerakan review kurikulum di berbagai tingkatan pendidikan untuk mengembangkan pengetahuan, sikap dan tindakan anti radikalisasi agama ini. Dalam forum Focus Group Discussion (FGD) yang diselenggarakan di Dewan Pertimbangan Presiden (Wantimpres), pada 7 April 2011, Nur Syam mengemukakan bahwa melakukan tindakan preventif terhadap gerakan radikalisme akan jauh lebih baik daripada tindakan kuratif lainnya, misalnya memerangi atau menghakimi. Tindakan preventif atau pencegahan tentu menjadi cara yang baik di

\footnotetext{
${ }^{1}$ Johan Galtung, Peace by Peacefull Mean. Peace and Peace Development and Civilization, (Oslo: PRIO) 2001. Hal. 1-2.

${ }^{2}$ Sudarto, Wacana Islam Progresif,(Jogjakarta: IRCiSod), 2014, hal. 120.
}

66 | FaLASIFA, Vol. 10 Nomor 1 Maret 2019 
Perguruan Tinggi Berbasis Pesantren dan Peranannya dalam Deradikalisasi Agama

tengah usaha untuk membersihkan Indonesia dari kasus-kasus terorisme yang terus berkembang. Lebih lanjut lagi, Beliau pun mengakui untuk mengembangkan gerakan deradikalisasi di kalangan perguruan tinggi tentunya akan sangat rumit. Tantangannya bukan hanya dari mahasiswa yang sudah menjadi eksponen gerakan Islam radikal, akan tetapi juga dosen-dosen di PT. Oleh karena itu, tulisan ini mencoba mengurai tentang penyebab radikalisme dan beberapa upaya perguruan tinggi berbasis pesantren dalam deradikalisme.

\section{PEMBAHASAN}

\section{Radikalisme Agama}

Radikalisme (al-tatarruf) secara bahasa artinya adalah berdiri di posisi ekstrem dan jauh dari posisi tengah-tengah atau melewati batas kewajaran.Dalam istilah klasik, teks-teks agama menyebut radikalisme dengan "al-ghulwu", "altasyaddud", dan "al-tanaththu". Allah berfirman, "Katakanlah: Hai Abli Kitab, janganlah kamu berlebih-lebihan (melampani batas) dengan cara tidak benar dalam agamamu" (QS. 5:77). Rasulullah bersabda, "Jaubilah perilaku melampani batas.Sesunggubnya kerusakan umat terdahulu disebabkan oleh perilaku yang melampuai batas dalam agama". Hadis shahih ini muncul dalam rangka mengkritik perilaku sahabat yang melewati batas dalam melempar jumrah dengan menggunakan batu yang besar.Meskipun hadis ini muncul dalam konteks historis yang khusus, namun beberapa ulama menyatakan bahwa hadis ini berlaku untuk semua bentuk radikalisme. Secara istilah, radikalisme adalah fanatik kepada satu pendapat serta menegaskan pendapat orang lain, mengabaikan terhadap kesejarahan Islam, tidak dialogis, suka mengkafirkan kelompok lain yang tak sepaham, dan tekstual dalam memahami teks agama tanpa mempertimbangkan tujuan esensial syariat (maqashid al-syari'at). ${ }^{3}$

Menurut Azyumardi Azra radikal adalah suatu kondisi atau orang dan gerakan yang menginginkan terjadinya perubahan sosial dan politik secara cepat dan menyeluruh dengan cara-cara tanpa kompromi, bahkan menggunakan kekerasan. ${ }^{4}$ Sedangkan orang yang radikal sebenarnya adalah orang yang mengerti sebuah permasalahan sampai keakar-akarnya, dank arena itu mereka lebih sering memegang teguh sebuah prinsip dibandingkan orang yang tidak mengerti akar masa-

${ }^{3}$ Irwan Masduqi, Deradikalisasi Pendidikan Islam Berbasis Khazanah Pesantren, (Jurnal Pendidikan Islam Volume I, Nomor 2, Desember 202/434) Hal. 2

${ }^{4}$ Azyumardi Azra, Konflik Baru Antar Peradaban Globalisasi, Radikalisme of Pluralitas, (Jakarta: RajaGrafindo Persada), 2002, hal. 112

FALASIFA, Vol. 10 Nomor 1 Maret 2019 | 67 


\section{Fadlilah}

lah. ${ }^{5}$ Dengan demikian radikalisme merupakan gejala umum yang bisa terjadi dalam suatu masyarakat dengan motif beragam, baik sosial, politik, budaya maupun agama, yang ditandai oleh tindakan-tindakan keras, ekstrim, dan anarkis sebagai wujud penolakan terhadap gejala yang dihadapai. ${ }^{6}$

Islam radikal yang kelihatan semakin visible, vokal dan bahkan militan setelah terjadinya liberalisasi politik berikut dengan jatuhnya presiden soeharto dari kekuasannya, pada tingkat wacana dan ideologi keagamaan kelihatannya memang radikal dalam pengertian, bahwa mereka menginginkan perubahan pandangan dunia kaum muslimin Indonesia umumnya, misalnya dengan penerapan syariah Islam, pembentukan Negara Islam (dawlah Islamiyah), atau bahkan Khilafah universal bagi semua umat Islam sedunia. Gejala Islam radikal juga terlihat dalam paksis mereka seperti razia terhadap diskotik dan tempat hiburan/maksiat lainnya, pengerahan pasukan jihad, dan sebagainya. Radikalisme lebih jauh, bukan tidak mungkin akan muncul, terutama ketika pemerintah semakin tidak berdaya melakukan law enforcement dan organisasi mainstream umat Islam, tidak asertif dan melakukan langkah-langkah tertentu untuk mengantisipasi gejala radikalisasi tersebut. $^{7}$

\section{Ciri-Ciri Radikalisme}

Kelompok radikal memiliki ciri-ciri antara lain; pertama, sering mengklaimkebenaran tunggal dan menyesatkan kelompok lain yang tak sependapat. Klaim kebenaran selalu muncul dari kalangan yang seakan-akan mereka adalah Nabi yang tak pernah melakukan kesalahan (ma'sum), padahal mereka hanya manusia biasa.Klaim kebenaran tidak dapat dibenarkan karena manusia hanya memiliki kebenaran yang relatif dan hanya Allah yang tahu kebenaran absolut.Oleh sebab itu, jika ada kelompok yang merasa benar sendiri maka secara langsung mereka telah bertindak congkak merebut otoritas Allah.

Kedua, radikalisme mempersulit agama Islam yang sejatinya sambah (ringan) dengan menganggap ibadah sunnah seakan-akan wajib dan makruh seakanakan haram. Radikalisme dicirikan dengan perilaku beragama yang lebih memprioritaskan persoalan-persoalan sekunder dan mengesampingkan yang primer.Contoh-contohnya adalah fenomena memanjangkan jenggot dan meninggi-

${ }^{5}$ Suprihatiningsih, Spiritualitas Gerakan Radikalisme Islam di Indonesia, (Jurnal Ilmu Dakwah, Vol. 32 No. 2, Juli-Desember 2012) hal. 371.

${ }^{6}$ Mohammad Kosim, Pesantren dan Wacana Radikalisme, (KARSA, Vol. IX No. 1 April 2006) Hal. 884.

${ }^{7}$ Azyumardi Azra, Konflik Baru Antar Peradaban Globalisasi, Radikalisme \& Pluralitas, hal. 114.

68 | FaLASIFA, Vol. 10 Nomor 1 Maret 2019 
Perguruan Tinggi Berbasis Pesantren dan Peranannya dalam Deradikalisasi Agama

kan celana diatas mata kaki. Umat Islam seyogianya memprioritaskan kewajiban ketimbang hal-hal sunnah yang sepele. Sudahkah zakat menyelesaikan problem kemiskinan umat?Sudahkah shalat menjauhkan kita dari berbuat kemungkaran dan kekacauan sosial?Dan sudahkah haji menciptakan kesadaran kesetaraan dalam Islam?Hal-hal seperti ini seyogyanya diutamakan ketimbang hanya berkutat mengurusi jenggot dan celana.

Ketiga, kelompok radikal kebanyakan berlebihan dalam beragama yang tidak pada tempatnya.Dalam berdakwah mereka mengesampingkan metode gradual yang digunakan oleh Nabi, sehingga dakwah mereka justru membuat umat Islam yang masih awam merasa ketakutan dan keberatan.Padahal QS.2:85 sudah menegaskan bahwa Allah menghendaki hal-hal yang meringankan dan tidak menghendaki hal-hal yang memberatkan umat-Nya.

Keempat, kasar dalam berinteraksi, keras dalam berbicara dan emosional dalam berdakwah.Ciri-ciri dakwah seperti ini sangat bertolakbelakang dengan kesantunan dan kelembutan dakwah Nabi dalam QS. 3:59. Dalam QS. 6:25 Allah juga menganjurkan umat Islam supaya berdakwah dengan cara yang santun dan menghindari kata-kata kasar. Anjuran yang senada datang dari sabda Rasulullah "Sesunggubnya Allab mencintai kelembutan dalam segala hal" dan "Kelembutan tidak masuk dalam sebuah hal kecuali membuatnya indah sedangkan kekerasan tidak masuk dalam sebuah hal kecuali hanya akan memperburuknya".

Kelima, kelompok radikal mudah berburuk sangka kepada orang lain di luar golongannya. Mereka senantiasa memandang orang lain hanya dari aspek negatifnya dan mengabaikan aspek positifnya. Hal ini harus dijauhi oleh umat Islam, sebab pangkal radikalisme adalah berburuk sangka kepada orang lain. Berburuk sangka adalah bentuk sikap merendahkan orang lain. Kelompok radikal sering tampak merasa suci dan menganggap kelompok lain sebagai ahli bid'ah dan sesat.

Keenam, mudah mengkafirkan orang lain yang berbeda pendapat. Di masa klasik sikap seperti ini identik dengan golongan Khawarij, kemudian di masa kontemporer identik dengan Jamaah Takfir wa al-Hijrah dan kelompok-kelompok puritan. Kelompok ini mengkafirkan orang lain yang berbuat maksiat, mengkafirkan pemerintah yang menganut demokrasi, mengkafirkan rakyat yang rela terhadap penerapan demokrasi, mengkafirkan umat Islam di Indonesia yang menjunjung tradisi lokal, dan mengkafirkan semua orang yang berbeda pandangan dengan mereka sebab mereka yakin bahwa pendapat mereka adalah pendapat Allah. ${ }^{8}$

Lebih detil, Rubaidi menguraikan lima ciri gerakan radikalisme Islam. Per-

\footnotetext{
${ }^{8}$ Irwan Masduqi, Deradikalisasi Pendidikan Islam Berbasis Khazanah Pesantren, Hal.
} $3-4$ 
tama, menjadikan Islam sebagai ideologi final dalam mengatur kehidupan individual dan juga politik ketata negaraan.Kedua, nilai-nilai Islam yang dianut mengadopsi sumbernya-di Timur Tengah-secara apa adanya tanpa mempertimbangkan perkembangan sosial dan politik ketika Al-Qur'an dan hadits hadir di muka bumi ini, dengan realitas lokal kekinian. Ketiga, karena perhatian lebih terfokus pada teks Al-Qur'an dan hadits, maka purifikasi ini sangat berhati-hati untuk menerima segala budaya non-asal Islam (budaya Timur Tengah) termasuk berhati-hati menerima tradisi lokal karena khawatir mencampuri Islam dengan bid'ah. Keempat, menolak ideologi Non-Timur Tengah termasuk ideologi Barat, seperti demokrasi,sekularisme dan liberalisasi.Sekali lagi, segala peraturan yang ditetapkanharus merujuk pada Al-Qur'an dan hadits.Kelima, gerakan kelompok inisering berseberangan dengan masyarakat luas termasuk pemerintah.Olehkarena itu, terkadang terjadi gesekan ideologis bahkan fisik dengankelompok lain, termasuk pemerintah. $^{9}$

\section{Penyebab Radikalisme}

Menurut mantan Kepala Badan Nasional Penanggulangan Terorisme (BNPT), Ansyaad Mbai, melihat sejumlah alasan munculnya gerakan radikalisasi Islam di Indonesia, yaitu kemiskinan, korupsi, globalisasi, dan sejarah. ${ }^{10}$ Pandangan serupa disampaikan Muhammad Tholhah Hasan, yang menilai munculnya gerakan radikalisme di Indonesia terutama setelah Reformasi disebabkan variabel ajaran dan pemahaman, peranan media internet (IT), kondisi sosial domestik, dan konstalasi politik internasional.

Lebih detail lagi, Abdul Munip memberikan penjelasan tentang sumbersumber yang menyebabkan radikalisme keagamaan yaitu: pertama, Pemahaman keagaaman yang literal, sepotong-potong terhadap ayat-ayat al-Qur'an. Pemahaman seperti itu hampir tidak memberikan ruang bagi akomodasi dan kompromi dengan kelompok-kelompok muslim lain yang umumnya moderat. Kedua, Bacaan yang salah terhadap sejarah Islam yang dikombinasikan dengan idealisasi berlebihan terhadap Islam pada masa tertentu, ini terlihat dalam pandangan dan gerakan salafi, khususnya pada spectrum sangat radikal seperti Wahabiyah yang muncul di Semenannjung Arabia pada akhir abad 18 awal sampai dengan abad 19 dan terus merebak sampai sekarang ini. Tema kelompok dan sel salafi ini adalah pemurniaan Islam, yakni membersihkan Islam dari pemahaman dan praktek kea-

${ }^{9}$ A. Rubaidi, Radikalisme Islam, Nabdlatul Ulama; Masa Depan Moderatisme Islam di Indonesia (Yogyakarta: Logung Pustaka), 2010, hal. 63

${ }^{10}$ Ahmad Darmadji, Pondok Pesantren dan Deradikalisasi Islam di Indonesia, (Millah Vol. XI, No 1, Agustus 2011), hal 10

70 | FaLASIFA, Vol. 10 Nomor 1 Maret 2019 
gaaman yang mereka pandang sebagai bid'ah yang tidak jarang mereka lakukan dengan cara kekerasan.

Ketiga, Deprivasi politik, sosial, dan ekonomi yang masih bertahan dalam masyarakat. Pada saat yang sama disorientasi dan dislokasi sosial budaya, dan ekses globalisasi, dan semacamnya sekaligus merupakan tambahan faktor-faktor penting bagi kemunculan kelompok-kelompok radikal. Kelompok-kelompok sempalan tersebut tidak jarang mengambill bentuk kultus (cult), yang sangat eksklusif, tetutup dan berpusat pada seseorrang yang dipandang kharismatik.Kelompokkelompok ini dengan dogma eskatologis tertentu bahkan memandang dunia sudah menjelang akhir zaman dan kiamat; sekarang waktunya bertaubat melalui pemimpin dan kelompok mereka.

Doktrin dan pandangan teologis-eskatologis seperti ini, tidak bisa lain dengan segera dapat menimbulkan reaksi dari agama-agama mainstream, yang dapat berujung pada konflik sosial. Radikalisme keagamaan jelas berujung pada peningkatan konflik sosial dan kekerasana bernuansa intra dan antaragama; bahkan juga anatar umat beragama dan Negara. Hal ini terlihat jelas misalnya; dengan meningkatnya aktivitas pentupan gereja di beberapa tempat dimana mayoritas kaum Muslim, seperti di Bekasi, Bogor dan Temanggung, atau penutupan masjid/musholla di daerah mayotitas non-Muslim diberbagai tempat di tanah air, seperti di Bali pasca bom bali oktober 2002. Lalu ada juga kelompok-kelompok hardliners atau garis keras dikalangan kaum muslim, menegakkan hukumnya sendiri atas nama syari'ah (hukum islam) seperti pernah dilakukan lasykar jihad di Ambon ketika terjadinya konflik komunal Kristen-Muslim; atau razia-razia yang dilakukan Front Pembela Islam (FPI) dalam beberapa tahun terakhir dengan mengatasnamakan al-amr bi al-ma'ruf wa al-nahy 'an al-munkar (menyeru dengan kebaikan dan mencegah kemungkaran). ${ }^{11}$

Imamduddin Rahmat juga menambahkan tentang diletakkannya perjuangan jihad, Jihad ditempatkan sebagai pilar perjuangan menegakkan syariat Islam. Mengenai doktrin jihad, Abdul Hasib mengutip ungakapan Hasan al-Banna, bahwa ada tiga macam kekuatan yaitu kekuatan aqidah, kekuatan umat, persatuan,kejamaahan, dan kekuatan fisik dan senjata. Dalam al-Qur'anpun penggunaan kekuatan fisik dan senjata fungsinya untuk melindungi ditegakkannya kebenaran.Jihad sebagai pilar menuju nizam Islami (tatanan Islam).Untuk mewujudkan tatanan Islami diperlukan upaya yang bersungguh-sungguh.Sebab mereka harus menghancurkan tatanan jahiliyah dan menaklukkan kekuasan-kekuasaan duniawi

\footnotetext{
${ }^{11}$ Abdul Munip, Menangkal Radikalisme Agama di Sekolah, (jurnal pendidikan Islam Volume I Nomor 2 Desember 2012.Hal 168.
}

FALASIFA, Vol. 10 Nomor 1 Maret $2019 \mid 71$ 


\section{Fadlilah}

mereka, melalui jiha perang suci. Tujuan jihad adalah menaklukkan semua halangan yang mungkin akan menghambat penyiaran Islam ke seluruh dunia, apakah halangan itu berupa Negara, sistem sosial, dan tradisi-tradisi asing. Atas dasar doktrin seperti ini muncullah beberapa gerakan-gerakan Islam mengatasnamakan jïhad fi sabilillah, pemahaman doktrin jihad yang keliru ini menyebabkan aksi terror dimana-mana mulai dari serangkaian kekerasan fisik, anarkisme, dan kontak senjata bahkan bom yang diledakkan. ${ }^{12}$

\section{Peranan Perguruan Tinggi Berbasis Pesantren dalam Deradikalisasi}

Peranan perguruan tinggi dalam mempersiapkan daya saing bangsa mengarungi era persaingan global sudah sangat urgen.Pada umumnya pendidikan tinggi di negara ini telah tertinggal, bahkan terasing dari kebutuhan dan realitas sosial, ekonomi, serta budayamasyarakatnya.Perguruan tinggi memerlukan otonomi danindependensi untuk dapat memulihkan perannya itu keluar darimenara gading dan terlibat secara langsung sebagai agent of changedalam perubahan masyarakat.

Memposisikan sebuah perguruan tinggi pada barisanperguruan tinggiperguruan tinggi terbaik memerlukan perubahanyang fundamental sehingga mampu bersaing (better competitivesituation).Sebuah perguruan tinggi harus memiliki strategic intent.Untuk mewujudkannya perlu dilakukan transformasi kelembagaanyang lebih kompleks dari sekadar pengembangan organisasi(organization development).Perguruan tinggi merupakan lembaga,dibangun komunitas akademik yang bersifat kolegial, dan menjunjung tinggi academic value untuk mencerdaskan bangsa. Ini yang membedakannya dengan organisasi lain. Melakukan perubahanfundamental untuk dapat menghasilkan nilai-nilai akademik, sosial,dan ekonomi merupakan kata kunci dalam transformasi sebuahperguruan tinggi. Transformasi kelembagaan ini mencakuppenyelarasan atau perancangan ulang dari strategi, struktur, sistem,stakeholders relation, staff, skills (competence), style of leadership, dan shared value.

Perguruan Tinggi berbasis Pesantren yang landasan utamanya terdiri dari prinsip-prinsip perjuangan, pengabdian, pengorbanan, jihad, ijtihad, dan mijahadah yang dijiwai oleh nilai-nilai keikhlasan, kesederhanaan, percaya diri dan kemandirian, persaudaraan, dan kebersamaan, serta kebebasan berfikir positif dan produktif merupakan sendi utama dan dasar dalam manajemen pengelolaan-

${ }^{12}$ M. Imdadun Rahmat, Arus Baru Islam Radikal Transmisi Revivalisme Islam Timur Tengah ke Indonesia, (Erlangga), hal, 151-159.

72 | FaLASIFA, Vol. 10 Nomor 1 Maret 2019 
Perguruan Tinggi Berbasis Pesantren dan Peranannya dalam Deradikalisasi Agama

nya. ${ }^{13}$ Transformasi perguruan tinggi berbasis pesantren dinilai pas untuk membendung faham radikalisme yang sudah mulai masuk dilingkungan mahasiswa bahkan dosen di perguruan tinggi.

Zuly qadir, mengungkapkan jalan yang terbaik dalam mengusung deradikalisasi adalah membangun deradikalisasi agama melalui pendidikan. Kiranya sangat diperlukan gerakan review kurikulum diberbagai tingkatan pendidikan untuk mengembangkan pengetahuan, sikap dan tindakan anti radikalisasi agama ini.

Deradikalisasi adalah upaya sistematis untukmembangun kesadaran masyarakat bahwa fanatisme sempit,fundamentalisme, dan radikalisme berpotensi membangkitkan terorisme. ${ }^{14}$ Deradikalisasi dapat pula dipahami sebagai segala upaya untukmenetralisasi paham-paham radikal melalui pendekatan interdisipliner,seperti agama, psikologi, hukum serta sosiologi, yang ditujukan bagimereka yang dipengaruhi faham radikal.

Abdul munip memberikan penjelasan tentang beberapa upaya yang bisa ditempuh untuk menanggulangi paham radikalisme di lembaga pendidikan antara lain:

1. Memberikan penjelasan tentang Islam secara memadai.

Misi ajaran Islam yang sebenarnya sangat mulia dan luhur seringkali justru mengalami distorsi akibat pemahaman yang keliru terhadap beberapa aspek ajaran Islam yang berpotensi menimbulkan faham radikalisme. Beberapa diantaranya adalah:

Penjelasan tentang jihad.Jihad adalah konsep ajaran Islam yang paling sering menimbulkan kontroversi dikalangan umat.Bagi kaum radikalis, jihad selalu bermakna qital atau peperangan atau perjuangan dengan mengangkat senjata.Sebenarnya makna jihad mempunyai arti yang beragam, meskipun salah satu artinya perang melawan musuh Islam.Kata jihad secara harfiah dan istilah mempunyai makna yang beragam.Dalam Ensiklopedia Islam Indonesia misalnya, makna kata jihad diartikan; berbuat sesuatu dengan secara maksimal, atau mengorbankan segala kemampuan. Arti lain dari kata jihad adalah berjuang/sungguh-sungguh. Tetapi bila dilihat dari sudut ilmu fiqh, jihad dapat dimaknai secara kontekstual sehingga bisa memiliki pengertian berbeda-beda.

Pemaknaan jihad yang berbeda-beda tersebut mempunyai akibat hukum syariat yang berbeda dan kadang bersinggungan dengan akidah.Sebagian ulama memaknai jihad sebagai usaha mengerahkan segala kemampuan yang ada

${ }^{13}$ Mardiyah, Manajemen Perguman Tinggi Berbasis Nilai-Nilai Pesantren, (Al-Ta'dib Volume 4 Nomor 2 Januari 2015) hal, 132.

${ }^{14}$ Nasir Abbas, Berdayakan Potensi Masyarakat dalam Pemberantasan Terorisme, (Komunika, 12 (VII) Juli 2011) hal. 5

FALASIFA, Vol. 10 Nomor 1 Maret 2019 | 73 


\section{Fadlilah}

atau sesuatu yang dimiliki untuk menegakkan kebenaran dan kebaikan serta menentang kebatilan dan kejelekan dengan mengharap ridha Allah.Islam menegaskan, Jihad selain merupakan salah satu inti ajaran Islam, juga tidak bisa disimplifikasi sebagai sinonim kata qital dan harb (perang).Perang selalu merujuk kepada pertahanan diri dan perlawanan yang bersifat fisik, sementara jihad memiliki makna yang kaya nuansa.

Menurut Sjuhada Abduh dan Nahar Nahrawi setidaknya ada beberapa pengertian yang berkaitan dengan jihad, yaitu: Perang. Islam mengajarkan kepada pemeluknya untuk tidak pernah gentar berperang di jalan Allah. Apabila kaum muslim dizalimi, fardlu kifayah bagi kaum muslim untuk berjihad dengan harta, jiwa dan raga. Jihad dalam bentuk peperangan dijinkan oleh Allah dengan beberapa syarat; untuk membela dri dan melindungi dakwah.Hal dini dijelaskan dalam firman Allah QS.An-Nisa' (4); 75.

Haji mabrur.Haji yang mabrur merupakan ibadah yang setara dengan jihad.Bahkan, bagi perempuan, haji yang mabrur merupakan jihad yang utama. Hal ini ditegaskan dalam beberapa hadis, diantaranya sebagai berikut: Aisyah RA berkata; "wahai Rasululah, kami memandang bahwa jihad adalah amalan yang paling afdhal. Apakah berarti kami harus berjihad?Tidak jihad yang paling utama adalah haji mabrur". Jawab Nabi SAW (HR. Bukhari)

Menyampaikan kebenaran kepada penguasa yang zalim. Perintah jihad melawan penguasa yang zalim disebutkan, antara lain, dalam hadis riwayat atTirmizi: Abu Said al-Khudri menyatakan bahwa Rasulullah SAW bersabda; sesungguhnya diantara jihad yang paling besar adalah menyampaikan kebenaran kepada penguasa yang zalim.

Berbakti kepada orang tua merupakan bentuk dari jihad.Islam mengajarkan kepada pemeluknya untuk menghormati dan berbakti kepada orang tua, tidak hanya ketika mereka masih hidup tetapi juga sampai kedua orang tua wafat.Seorang anak tetap harus menghormati orangtuanya, meskipun seorang anak tidak wajib taat terhadap orang tua yang memaksanya berbuat musyrik (QS.Luqman, (31); 14).Perintah berbakti kepada orantua merupakan jihad termaktub dalam hadis Nabi dalam shahih Bukhari; "Seseorang datang kepada Nabi SAW untuk meminta izin ikut berjihad bersamanya.Kemudian Nabi SAW bertanya; apakah kedua orangtuamu masih hidup!Ia menjawab; masih, Nabi SAW bersabda; terhadap keduanya maka berjihadlah kamu”.Berjihad untuk orang tua, berarti melaksanakan petunjuk, arahan, bimbingan dan kemauan orangtua.

Bentuk jihad yang lainnya adalah menuntut ilmu dan mengembangkan, memajukan pendidikan masyarakat. Didalam sebuah hadis yang diriwayatkan 
Perguruan Tinggi Berbasis Pesantren dan Peranannya dalam Deradikalisasi Agama

Ibnu Majah disebutkan; "Orang yang datang ke masjidku ini tidak lain kecuali karena kebaikan yang dipelajarinya atau diajarkannya, maka Ia sama dengan orang berjihad di jalan Allah. Barang siapa yang datang bukan karena itu, maka sama dengan orang yang melihat kesenangan orang lain”. Hal ini senada dengan firman Allah SWT Yang artinya. "Hai orang-orang beriman apabila kamu dikatakan kepadamu: "Berlapang-lapanglah dalam majlis", Maka lapangkanlah niscaya Allah akan memberi kelapangan untukmu. dan apabila dikatakan: "Berdirilah kamu", Maka berdirilah, niscaya Allah akan meninggikan orang-orang yang beriman di antaramu dan orang-orang yang diberi ilmu pengetahuan beberapa derajat. dan Allah Maha mengetahui apa yang kamu kerjakan."(QS. AlMujadalah (58); 11).

Jihad yang tidak kalah pentingnya adalah membantu orang miskin, peduli kepada sesama, menyantuni kaum duafa.Bantuan pemberdayaan dapat diberikan dalam bentuk perhatian dan perlindungan atau bantuan material. Anjuran membantu orang miskin, peduli sesama terdapat dalam hadis shahih Bukhari; " Dari Abu Hurairah berkata; Rasulullah SAW bersabda; orang yang berusaha menannggung para janda dan orang miskin itu sama seperti orang yang berjihad di jalan Allah, orang yang qiyam (menegakkan sholat) malam tanpa istirahat dan seperti orang yang berpuasa tanpa berbuka (HR. Muslim. Bukhari.At-Turmuzi. Ibnu Majah. Ahmad)

Lebih lanjut lagi, diantara misi ajaran Islam yang sebenarnya sangat mulia dan luhur seringkali justru mengalami distorsi akibat pemahaman yang keliru terhadap beberapa aspek ajaran Islam yang berpotensi menimbulkan faham radikalisme adalah penjelasan tentang toleransi.Ajaran Islam sebenarnya sangat sarat dengan nilai-nilai toleransi.Namun sayang, toleransi sering dipahami secara sempit sehingga tidak mampu menjadi lem perekat intra dan antar umat beragama. Setidaknya, ungkapan Zuhairi Misrawi dalam bukunya al-Quran Kitab Toleransi: Inklusivisme, Pluralisme, Multikulturalisme, bisa menjadi salah satu pijakan dalam menjelaskan toleransi dalam Islam. Al-Quran, yang menegaskan Islam sebagai rahmat bagi alam semesta, secara gambling mengakui kemajemukan keyakinan dan agama. Ratusan ayat secara eksplisit menyerukan sikap santun toleran terhadap umat agama lain.

Pengenalan tentang hubungan ajaran Islam dengan kearifan lokal termasuk diantara beberapa misi ajaran Islam yang sebenarnya sangat mulia dan luhur seringkali justru mengalami distorsi akibat pemahaman yang keliru terhadap beberapa aspek ajaran Islam yang berpotensi menimbulkan faham radikalisme.Islam yang datang di Arabia bukanlah Islam yang bebas dari relasi sejarah lokal yang mengitarinya.Artinya, memahami Islam tidak bisa dicerabut da- 
Fadlilah

ri akar sosio-historis dimana Islam berada.Keberadaan Islam di Indonesia juga tidak bisa dilepaskan dari kondisi sosio-historis masyarakat Indonesia yang juga telah memiliki kearifan lokal. Dengan pemahaman seperti ini, Islam bisa diterima dan hidup secara berdampingan dengan tradisi lokal yang sudah mengalami proses Islamisasi.

2. Mengedepankan dialog dalam pembelajaran Agama Islam.

Pembelajaran Agama Islam mengedepankan indoktrinasi faham tertentu dengan mengesampingkan faham yang lain hanya akan membuat para siswa memiliki sifat ekslusif yang pada gilirannya kurang menghargai keberadaan liyan atau others. Sudah saatnya para guru PAI membekali dirinya dengan pemahaman yang luas dan lintas madzhab sehingga mampu memenuhi kehausan spiritual siswa dan mahasiswa dengan pencerahan yang bersendikan kedamaian dan kesejukan ajaran Islam.

3. Pemantauan terhadap kegiatan dan materi monitoring keagamaan.

Keberadaan kegiatan mentoring agama Islam atau kegiatan Rohis yang lain di sekolah sesungguhnya sangat membantu tercapainya tujuan pendidikan agama Islam. Namun, jika guru PAI tidak melakukan pendampingan dan monitoring, dikhawatirkan terjadi pembelokan kegiatan mentoring dan Rohis lainnya. Bagi pengurus Rohis, sudah seharusnya mereka selalu berkonsultasi dengan pihak guru Agama atau pihak-pihak lain yang dipandang memiliki wawasan keislaman moderat agar tidak terbawa arus pada pemahaman Islam yang sarat dengan muatan Radikalisme

4. Pengenalan dan penerapan pendidikan multicultural.

Pendidikan multicultural pada dasarnya adalah konsep dan praktek pendidikan yang mengedepankan nilai-nilai persamaan tanpa melihat perbedaan latar belakang budaya, sosial-ekonomi, etnis, agama, gender, dan lain-lain. Semua orang memiliki kesempatan yang sama untuk memperoleh hak pendidikan. Dengan penerapan pendidikan multikultural, diharapkan semangat eksklusif dan merasa benar sendiri sebagai penyebab terjadinya konflik dengan liyan atau others bisa dihindari.Seorang multikulturalis sejati adalah pribadi yang selalu bersikap toleran, menghargai keberadaan liyan tanpa dia sendiri kehilangan identitasnya. Kalau tujuan akhir pendidikan adalah perubahan perilaku dan sikap serta kualitas seseorang, maka pengajaran harus berlangsung sedemikian rupa sehingga tidak sekedar memberi informasi atau pengetahuan melainkan harus menyentuh hati, sehingga akan mendorongnya dapat mengambil keputusan untuk berubah.

Pendidikan agama Islam, dengan demikian, disamping bertujuan untuk memperteguh keyakinan pada agamanya, juga harus diorientasikan untuk mena-

76 | FaLASIFA, Vol. 10 Nomor 1 Maret 2019 
Perguruan Tinggi Berbasis Pesantren dan Peranannya dalam Deradikalisasi Agama

namkan empati, simpati dan solidaritas terhadap sesame.Dengan demikian, dalam hal ini, semua materi buku-buku yang diajarkannya tentunya harus menyentuh tentang isu pluralitas. Dari sinilah kemudian kita akan mengerti urgensinya untuk menyusun bentuk kurikulum pendidikan agama berbasi pluralisme agama. ${ }^{15}$

Peran seorang tenaga pendidik (guru/dosen) dalam deradikalisasi juga tidak kalah penting setidaknya ada beberapa hal yang harus diperhatikan oleh seorang pendidik (guru/dosen).pertama, seorang guru/dosenharus mampu bersikap demokratis, baik dalam sikap maupun perkataannya tidak diskriminatif. Kedua, guru/dosen seharusnya mempunyai kepedulianyang tinggi terhadap kejadiankejadian tertentu yang ada hubungannya dengan agama.Misalnya, ketika terjadi bom Bali (2003), maka seorang guru yang berwawasan multikultural harus mampu menjelaskan keprihatinannya terhadap peristiwa tersebut.Ketiga, guru/dosen seharusnya menjelaskan bahwa inti dari ajaran agama adalah menciptakan kedamaian dan kesejahteraan bagi seluruh umat manusia, maka pemboman, invasi militer, dan segala bentuk kekerasan adalah sesuatu yang dilarang oleh agama.Keempat, guru/dosen mampu memberikan pemahaman tentang pentingnya dialog dan musyawarah dalam menyelesaikan berbagai permasalahan yang berkaitan dengan keragaman budaya, etnis, dan agama (aliran), misalnya, kasus penyerbuan dan pengusiran Jamaah Ahmadiyah di Lombok-NTB dan kekerasan pada jamaah Syiah di Sampang Madura baru-baru ini tidak perlu terjadi, jika wacana inklusivisme beragama ditanamkan pada semua elemen masyarakat termasuk peserta didik. ${ }^{16}$

Sejalan dengan hal tersebut, setidaknya ada lima tugas utama pendidikan (agama) Islam, khususnya di PerguruanTinggi Agama Islam (PTAI), dalam menghadapi keragaman agama, yaitu(1) mengenalkan isu-isu kontemporer yang dihadapi umat Islam, bersamaandengan upaya menjelaskan ajaran Islam klasik, (2) mengarahkan tujuanutama Islam pada pemecahan permasalahan mengenai hubungan antarmanusia, (3) mengkontekstualisasikan Islam, (4) mengkritisi penekananpendidikan agama hanya pada domain kognitif, dan (5) mendedikasikanIslam tidak semata-mata untuk pengembangan moralitas individu,melainkan juga

${ }^{15}$ Jalaludin Faruk Azhari, Peran Pendidikan Agama Islam dalam Deradikalisasi, ( Subulana, Vol. 1 No. 2 Maret 2018), hal 77.

${ }^{16}$ Indriyani Ma'rifah, "Rekonstruksi Pendidikan Agama Islam: Sebuah Upaya Membangun Kesadaran Multikultural untuk Mereduksi Terorisme dan Radikalisme Islam," Conference Proceedings Annual International Conference on Islamic Studies (AICIS) XII IAIN Sunan Ampel Surabaya 5-8 November 2012," hal. 236

FALASIFA, Vol. 10 Nomor 1 Maret 2019 | 77 
Fadlilah

moralitas publik. ${ }^{17}$

\section{KESIMPULAN}

Deradikalisasi dilingkungan perguruan tinggi nampaknya akan sulit terutama perguruan tinggi berbasis pesantren. Tantangan yang akan dihadapi bukan dari faktor internal saja seperti mahasiswa dan para dosen melainkan juga faktor eksternal yang tidak bisa dijangkau melalui nalar. Sebagaimana diketahui bahwa ideologi radikalismeini merupakan ideologi yang sangat kuat tertanam di dalam diri seseorang.Ketika seseorang sudah masuk di dalamnya, maka akan sangat sulit keluar.Yang mungkin adalah menjadi semakin kuat dan bertambah kuat. Peranan perguran tinggi berbasis pesantren sangat diperlukan dalam mencetak generasi penerus bangsa yang intelektual, berkarakter (akhlak), religiu dan nasionalis sehingga mampu memberi pengertian, pemahaman, mentoring dan monitoring baik di sekolah ataupu masyarakat.Jika ada anggota masyarakat, peserta didik dilingkungan sekitar yang menunjukkan gejala terindikasi faham radikalisme, yang nampak dalam ciri-ciri fisik maupun jalan berpikirnya.Mereka bukan untuk dihindari tetapi perlu dirangkul dan diajak kembali ke jalan Islam yang penuh kedamaian, moderat, dan kesejukan. Tentu kita semua akan menyesal bila keluarga kita, anak didik bahkan masyarakat disekitar kita ternyata telah terjerumus begitu jauh pada faham-faham radikal.

\section{DAFTAR PUSTAKA}

Abdullah, M. Amin, Membangun Perguruan Tinggi Islam Unggul dan Terkemuka (Yogyakarta: Suka Press), 2010

Abbas, Nasir, Berdayakan Potensi Masyarakat dalam Pemberantasan Terorisme, (Komunika, 12 (VII) Juli 2011)

Azra, Azyumardi, Konflik Baru Antar Peradaban Globalisasi, Radikalisme \& Pluralitas, (Jakarta: RajaGrafindo Persada), 2002

A. Rubaidi, Radikalisme Islam, Nabdlatul Ulama; Masa Depan Moderatisme Islam di Indonesia (Yogyakarta: Logung Pustaka), 2010

Darmadji, Ahmad, Pondok Pesantren dan Deradikalisasi Islam di Indonesia, (Millah Vol. XI, No 1, Agustus 2011)

Faruk Azhari, Jalaludin, Peran Pendidikan Agama Islam dalam Deradikalisasi, Subulana, Vol. 1 No. 2 Maret 2018)

${ }^{17}$ M. Amin Abdullah, Membangun Perguman Tinggi Islam Unggul dan Terkemu$k a$ (Yogyakarta: Suka Press) 2010, hal. 139-140

78 | FaLASIFA, Vol. 10 Nomor 1 Maret 2019 
Perguruan Tinggi Berbasis Pesantren dan Peranannya dalam Deradikalisasi Agama

Galtung,Johan, Peace by Peacefull Mean. Peace and Peace Development and Civilization, (Oslo: PRIO) 2001

Kosim, Mohammad, Pesantren dan Wacana Radikalisme, (KARSA, Vol. IX No. 1 April 2006)

Mardiyah, Manajemen Perguruan Tinggi Berbasis Nilai-Nilai Pesantren, (Al-Ta'dib Volume 4 Nomor 2 Januari 2015)

Masduqi,Irwan, Deradikalisasi Pendidikan Islam Berbasis Khazanah Pesantren, (Jurnal Pendidikan Islam Volume I, Nomor 2, Desember 202/434)

Munip, Abdul, Menangkal Radikalisme Agama di Sekolah, (jurnal pendidikan Islam Volume I Nomor 2 Desember 2012)

Ma'rifah, Indriyani, "Rekonstruksi Pendidikan Agama Islam: Sebuah Upaya Membangun Kesadaran Multikultural untuk Mereduksi Terorisme dan Radikalisme Islam," Conference Proceedings Annual International Conference on Islamic Studies (AICIS) XII IAIN Sunan Ampel Surabaya 5-8 November 2012

Rahmat, M. Imdadun, Arus Baru Islam Radikal Transmisi Revivalisme Islam Timur Tengah ke Indonesia, (Erlangga), tt.

Sudarto, Wacana Islam Progresif,(Jogjakarta: IRCiSod), 2014

Suprihatiningsih, Spiritualitas Gerakan Radikalisme Islam di Indonesia, (Jurnal Ilmu Dakwah, Vol. 32 No. 2, Juli-Desember 2012). 


\section{Fadlilah}

$80 \mid$ Falasifa, Vol. 10 Nomor 1 Maret 2019 